\title{
ANALISIS FAKTOR- FAKTOR YANG MEMPENGARUHI PRICE TO BOOK VALUE SAHAM PADA BANK DEVISA YANG LISTING DI BURSA EFEK INDONESIA PERIODE 2013-2014
}

\author{
Shelly Korina Diani \\ dshell.chorine@gmail.com \\ Universitas Ahmad Dahlan \\ Dyah Fitriani \\ dhifa_dhe@yahoo.com \\ Universitas Ahmad Dahlan
}

\begin{abstract}
ABSTRAK
This study aims to examine what factors affect the Price to Book Value (PBV) of shares in foreign exchange banks listed on the Indonesia Stock Exchange in the period 2013-2014 using indicators of CAR (Capital Adequacy Ratio), NPL (Non Performing) financial ratios Loans), LDR (Loan to Deposit ratio), Net Interst Margin (NIM), ROE (Return on Equity) and BOPO (Operating costs per Operating income) as independent variables and PBV (Price to Book Value) as the dependent variable. The sample used in this study amounted to 19 foreign exchange banks listed on the Indonesia Stock Exchange (IDX) for the 2013-2014 period. The statistical tool used to test the effect of the independent variable partially on the dependent variable is the $\mathrm{T}$ test, while to test the effect of the independent variable on the dependent variable simultaneously the $F$ test is used. The results of this study indicate that the partial test results of the $\mathrm{T}$ test are the first variable, namely Capital Adequacy Ratio (CAR) with a value of 0.019 significantly influences the Price to Book Value of banking industry shares, the second variable Non Performing Loans (NPL) with a value of 0.018 significantly influences the Price to Book Value of banking industry shares, the third variable is Loan to Dept Ratio (LDR) with the value of 0,000 has a significant effect on the Price to Book Value of the banking industry shares, the fourth variable Net Interest Margin (NIM) with a value of 0.003 has a significant effect on the Price to Book Value of the banking industry shares, then the fifth variable Return on Equity (ROE) with a value of 0.080 has no significant effect against Price to Book Value of banking industry shares, and the sixth variable Operational Cost per Operating Income (BOPO) with a value of 0.002 has a significant effect on Price to Book Value of banking industry shares.
\end{abstract}

Keyword : CAR (Capital Adequacy Ratio); NPL (Non Performing Loan); LDR (Loan to Deposit Ratio); NIM (Non Interest Margin); ROE (Return On Equity); BOPO (Biaya Operasional Per Pendapatan); PBV (Price to Book Value)

\section{PENDAHULUAN}

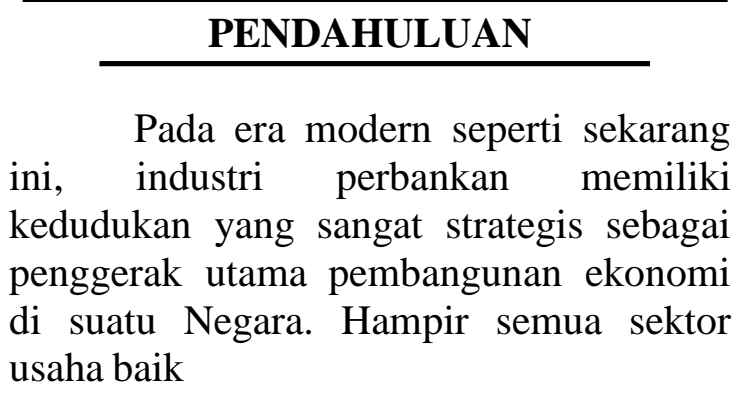

milik swasta maupun milik pemerintah sangat membutuhkan bank sebagai mitra usahanya dalam melakukan transaksi keuangan. Sektor usaha maupun individu pada saat ini dan masa yang akan datang tidak akan lepas dari sektor perbankan, bahkan sektor perbankan menjadi suatu kebutuhan dalam menjalankan aktivitas keuangan dalam mendukung kelancaran 
usaha. Bank adalah badan usaha yang menghimpun dana dari masyarakat dalam bentuk simpanan dan menyalurkannya kepada masyarakat dalam bentuk kredit dan/atau bentuk lainnya dalam rangka meningkatkan taraf hidup rakyat banyak. Fungsi utama bank yaitu memperlancar kegiatan perekonomian masyarakat terutama dalam kaitannya sebagai lembaga intermediasi yaitu lembaga perantara keuangan yang menyalurkan dana dari pihak yang berkelebihan dana (idle fund surplus unit) kepada pihak yang membutuhkan dana atau kekurangan dana (deficit unit) pada waktu yang ditentukan.

Seiring dengan perkembangan zaman, persaingan di dunia perbankan semakin ketat sejak adanya kebijakan pemerintah untuk melikuidasi bank-bank yang kurang sehat, terutama pada bankbank yang go public. Oleh karena itu, industri perbankan berusaha keras untuk mengelola usahanya agar memperoleh kepercayaan dari masyarakat dan tidak dilikuidasi. Terkait dengan rintangan pada sektor perbankan. Permasalahan yang dihadapi oleh bank adalah ketika keadaan perekonomian Indonesia memburuk akibat terkena imbas dari krisis global pada 2007, dimana banyak investor asing yang mengalami kesulitan likuiditas terpaksa menarik dana yang tadinya ditanamkan di Indonesia. Besarnya dampak krisis global melalui jalur finasial ini mempengaruhi kemampuan sektor-sektor ekonomi dalam melakukan pembiayaan ekonomi. Meskipun kondisi ketahanan bank cukup solid membuat perbankan cukup mampu dalam menyerap beberapa jenis risiko, diantaranya risiko nilai tukar, suku bunga, dan harga surat hutang Negara (SUN). Meskipun demikian, dampak krisis ke rektor riil berpotensi memunculkan risiko kredit yang akan mempengaruhi perbankan dalam penyaluran kreditnya. Lesunya kegiatan usaha dan meluasnya pemutusan hubungan kerja berpotensi meningkatkan terjadinya kredit macet bank dan pada lanjutannya akan menahan bank dalam menyalurkan kreditnya. Akibatnya, banyak bank yang kinerjanya menurun dan tidak memenuhi persyaratan kesehatan bank yang ditentukan pemerintah dan akhirnya dilikuidasi.

Bukan hanya pada sektor usaha dan perbankan, krisis moneter juga berdampak terhadap kegiatan pasar modal, dimana perdagangan saham perbankan yang terdapat di Bursa Efek Indonesia mengalami kemerosotan karena banyak investor yang menarik investasinya dari bank sehingga kinerja operasional bank mengalami penurunan. Hal ini terjadi Karena menurunnya kepercayaan investor terhadap perbankan akibat banyaknya kinerja bank yang menurun dan dilikuidasi. Dengan kondisi ekonomi yang seperti ini membuat para investor lebih berhatihati dalam menanamkan modalnya. Investor perlu memiliki informasi tentang kinerja bank yang akan mempengaruhi nilai sahamnya, sehingga investor dapat mengambil keputusan apakah saham tersebut layak atau tidak. Penilaian terhadap saham suatu perusahaan dapat menggunakan indikator PBV (Price to Book Value). PBV menggambarkan seberapa besar pasar menghargai nilai buku suatu saham. PBV merupakan perbandingan nilai pasar suatu saham terhadap nilai bukunya untuk dapat mengukur tingkat saham apakah overvalue atau undervalue.

Dalam

perkembangannya, perusahaan perbankan dituntut untuk dapat menjaga kinerjanya dengan baik. Bank yang dapat menjaga kinerjanya dengan baik terutama pada tingkat profitabilitas yang tinggi dan kemampuan untuk membayar dividen yang tinggi pada pemegang saham serta prospek usaha dapat selalu berkembang dan dapat memenuhi prudential banking regulation dengan baik maka kemungkinan nilai saham bank tersebut di pasar sekunder akan naik dan nilai PBVnya pun naik. Semakin besar kepercayaan masyarakat terhadap perusahaan maka akan semakin naik nilai sahamnya. Dalam melakukan 
penilaian kinerja bank dapat diukur dengan analisisi aspek permodalan (capital), aspe kualitas asset produktif (assets), aspek kualitas manajemen (management), aspek I laba (earning), dan aspek likuiditas (liquidity). Aspek-aspek tersebut I menggunakan rasio keuangan CAR (Capital Adequacy Ratio) sebagai indikator aspek capital, NPL (Non Performing Loan) sebagai indikator aspek asset, NPM (Net Profit Margin) sebagai indikator aspek manajemen, aspek earning memiliki indikator ROA (Return On Assets), ROE (Return on Equity), NIM (Net Interest Margin) dan BOPO (Biaya operasional dan Beban Operasional), serta aspek likuiditas memiliki indikator LDR (Loan to Deposit ratio). Kinerja keuangan yang baik akan mendorong semakin banyak investor untuk berinvestasi sehingga nilai saham akan naik dan berpengaruh terhadap PBV saham tersebut.

Berbagai penelitian mengenai analisis faktor yang mempengaruhi Price to Book Value saham pada bank yang terdaftar di Bursa Efek Indonesia telah banyak dilakukan dan memperoleh hasil yang berbeda-beda. Berdasarkan berbagai penelitian sebelumnya yang memperoleh hasil hubungan yang signifikan antara kinerja bank terhadap Price to Book Value saham, maka penelitian ini akan menganalisis rasio keuangan sebagai alat untuk menilai tingkat kesehatan bank sebagai faktor yang mempengaruhi price to book valuesaham pada perusahaan perbankan yang listing di Bursa Efek Indonesia. Indikator pengukur kinerja difokuskan pada rasio-rasio faktor CAMEL yang tercantum dalam Direktorat Perbankan Indonesia (2005-2009) yang terdiri dari faktor permodalan, faktor kualitas asset, faktor laba, dan faktor likuiditas. Rasio yang digunakan dalam penelitian ini adalah CAR (Capital Adequacy Ratio) sebagai indikator aspek capital, NPL (Non Performing Loan) sebagai indikator aspek asset, aspek laba memiliki indikator ROE (Return on
Equity), NIM (Net Interst Margin) dan BOPO (Biaya operasional per pendapatan Operasional), serta aspek likuiditas memiliki inndikator LDR (Loan to Deposit ratio)

\section{Rumusan Masalah}

1. Apakah Capital Adequacy Ratio (CAR) berpengaruh signifikan terhadap PBV saham pada perusahaan perbankan?

2. Apakah Non Performing Loan (NPL) berpengaruh signifikan terhadap PBV saham pada perusahaan perbankan?

3. Apakah Loan to Deposit Ratio (LDR) berpengaruh signifikan terhadap PBV saham pada perusahaan perbankan?

4. Apakah Return on Equity (ROE) berpengaruh signifikan terhadap PBV saham pada perusahaan perbankan?

5. Apakah Net Interest Margin (NIM) berpengaruh signifikan terhadap PBV saham pada perusahaan perbankan?

6. Apakah Biaya Operasional per Pendapatan Operasi (BOPO) berpengaruh signifikan terhadap PBV saham pada perusahaan perbankan?

7. Apakah Capital Adequacy Ratio (CAR), Non Performing Loan (NPL), Net Interest Margin (NIM), Loan to Deposit Ratio (LDR), Return on Equity (ROE) dan Biaya Operasional per Pendapatan Operasi (BOPO) secara simultan berpengaruh signifikan terhadap PBV saham pada perusahaan perbankan?

\section{REVIEW LITERATUR DAN HIPOTESIS}

\section{Landasan Teori \\ Definisi Bank}

Dalam pembicaraan sehari-hari, bank dikenal sebagai lembaga keuangan yang kegiatan utamanya menerima simpanan giro, tabungan, dan deposito. Kemudian bank juga dikenal sebagai tempat untuk meminjam uang (kredit) bagi masyarakat yang membutuhkannya. Disamping itu, bank juga dikenal sebagai 
tempat untuk menukar uang, memindahkan uang, atau menerima segala bentuk pembayaran dan setoran seperti pembiayaan listrik, telepon, air, pajak, uang kuliah, dan pembayaran lainnya. Menurut Undang-Undang RI Nomor 10 tahun 1998 tanggal 10 November 1998 tentang perbankan, yang dimaksud dengan BANK adalah badan usaha yang menghimpun dana dari masyarakat dalam bentuk simpanan dan menyalurkannya kepada masyarakat dalam bentuk kredit dan atau bentuk-bentuk lainnya dalam rangka meningkatkan taraf hidup masyarakat banyak.

\section{Analisis Rasio Keuangan}

Untuk menilai suatu kinerja bank dapat dilihat dari berbagai segi. Penilaian ini bertujuan untuk menentukan apakah bank tersebut dalam kondisi yang sehat, cukup sehat, kurang sehat dan tidak sehat sehingga Bank Indonesia sebagai pengawas dan Pembina bank-bank dapat memberikan arahan atau petunjuk bagaimana bank tersebut harus dijalankan atau bahkan dihentikan kegiatan operasinya.

Penilaian kinerja bank dilakukan untuk mengetahui apakah ada peningkatan atau penurunan. Bagi bank yang kinerjanya terus meningkat tidak jadi masalah, karena itulah yang diharapkan dan supaya dipertahankan terus kesehatannya. Akan tetapi, bagi bank yang kinerjanya terus-menerus turun, mungkin harus mendapat pengarahan atau sangsi dari bank Indonesia sebagai pengawas dan Pembina bank bank.

\section{Aspek Permodalan}

Yang dinilai adalah permodalan yang ada didasarkan kepada kewajiban penyediaan modal minimum bank. Penilaian tersebut didasarkan pada CAR (Capital Adequacy Ratio) yang telah ditetapkan bank Indonesia. CAR adalah rasio yang memperlihatkan seberapa jauh seluruh aktiva bank yang mengandung risiko (kredit, penyertaan, surat berharga,tagihan pada bank lain) ikut dibiayai dari dana modal sendiri bank, disamping memperoleh dana-dana dari sumber di luar bank, seperti dana masyarakat, pinjaman, dan lain-lain.

$$
C A R=\frac{\text { modal bank }}{\text { aktiva tertimbang menurut risiko }} \times 100 \%
$$

\section{Aspek Kualitas Asset}

Salah satu indikator untuk mengukur kualitas asset adalah Non Performing Loan (NPL). Menurut Kamus Bank Indonesia, Non Performing loan (NPL) atau Non Performing Financing (NPF) adalah kredit bermasalah yang terdiri dari kredit yang berklasifikasi kurang lancar, diragukan dan macet. Termin NPL diperuntukkan bagi bank umum, sedangkan NPF untuk bank syariah.

$$
\text { NPL }=\frac{\text { total NPL }}{\text { Total Kredit }} \times 100 \%
$$

\section{Aspek Kualitas Manajemen}

Net profit margin (NPM) adalah salah satu rasio indikator dari aspek manajemen yang menggambarkan tingkat keuntungan (laba) yang diperoleh bank dibandingkan dengan pendapatan yang diterima dari kegiatan operasionalnya. Rasio ini dapat dirumuskan sebagai berikut:

$$
\text { NPM }=\frac{\text { laba bersih }}{\text { pendapatan operasional }} \times 100 \%
$$

\section{Aspek Likuiditas}

LDR adalah risiko antara seluruh jumlah kredit yang diberikan bank dengan dana yang diterima oleh bank. Rasio ini menunjukkan salah satu penilaian likuiditas bank dan dapat dirumuskan sebagai berikut:

$$
L D R=\frac{\text { jumlah kredit yang diberikan }}{\text { total dana pihak ketiga }+K L B I+\text { Modal inti }} \times 100 \%
$$

\section{Aspek Rentabilitas}

Return on Equity (ROE) ROE adalah perbandingan antara laba bersih bank dengan ROE modal sendiri. Rasio ini dapat dirumuskan sebagai berikut: 
$R O E=\frac{\text { Laba bersih }}{\text { modal sendiri }} \times 100 \%$

BOPO (Biaya Operasional/ Pendapatan Operasional) asio biaya operasional adalah perbandingan antara biaya operasional dan pendapatan operasional. Rasio ini dapat dirumuskan sebagai berikut:

$$
B O P O=\frac{\text { Biaya }(\text { beban }) \text { operasioanl }}{\text { pendapatan operasional }} \times 100 \%
$$

\section{Saham}

Saham (stock) merupakan salah satu instrumen pasar keuangan yang paling popular. Menerbitkan saham merupakan salah satu pilihan perusahaan ketika memutuskan untuk pendanaan perusahaan. Pada sisi yang lain, saham merupakan instrument investasi yang banyak dipilih para investor karena saham mampu memberikan tingkat keuntungan yang menarik.

Saham dapat didefinisikan sebagai tanda penyertaan modal seseorang atau pihak (badan usaha) dalam suatu perusahaan atau perseroan terbatas. Dengan menyertakan modal tersebut, maka pihak tersebut memiliki klaim atas pendapatan perusahaan, klaim atas asset perusahaan, dan berhak hadir dalam Rapat Umum Pemegang Saham (RUPS).

\section{Price to Book Value (PBV)}

Price to book value (PBV) adalah hubungan antara harga pasar saham dan nilai buku per lembar saham bisa juga dipakai sebagai alternative untuk menentukan nilai suatu saham. PBV menggambarkan seberapa besar pasar menghargai nilai buku saham suatu perusahaan. Semakin tinggi rasio ini, maka pasar semakin percaya akan prospek perusahaan tersebut. PBV dihitung dengan:

$$
P B V=\frac{\text { harga saham }}{\text { nilai buku saham }}
$$

\section{Penelitian Terdahulu}

Hasan (2011) dalam penelitiannya yang berjudul " analisis faktor yang mempengaruhi price to book value saham (pada bank yang terdaftar di BEI periode 2005-2008)", menyatakan bahwa secara simultan variable CAR, NPL, LDR, ROE, NIM dan BOPO berpengaruh terhadap PBV saham pada taraf uji $\alpha=5 \%$. Sedangkan secara parsial variable CAR, ROE, NIM dan BOPO berpengaruh positif signifikan terhadap PBV saham pada taraf uji $\alpha=5 \%$. Sedangkan variable NPL dan LDR berpengaruh negative tidak signifikan terhadap PBV saham pada taraf uji $\alpha=5 \%$.

$$
\text { Marlina (2013) dalam }
$$

penelitiannya berjudul " Pengaruh Earning Per Share, Return On Equity, Debt To Equity Ratio dan Size Terhadap Price To Book Value", menyatakan bahwa Earning per Share, Return On Equity (ROE), Debt to Equity Ratio berpengaruh positif dan signifikan terhadap Price to book value, sedangkan Size berpengaruh negatif tidak signifikan terhadap price to book value. Namun demikian, Koefisien regresi Earning per Share (EPS), Return On Equity (ROE), Debt to Equity Ratio (DER), dan Size secara bersama-sama (simultan) berpengaruh signifikan terhadap Price to Book Value (PBV).

Aziz (2014) Dalam penelitiannya yang berjudul "Analisis Pengaruh Dept Equity Ratio (DER), Return on Assets (ROA), Earning per Share (EPS) Terhadap Price To Book Value (PBV) Pada Perusahaan Transportasi di Bursa Efek Indonesia Periode 2008-2012" menunjukkan bahwa secara simultan terdapat pengaruh yang dignifikan antara Dept Equity Ratio (DER), Return on Assets (ROA), Earning per Share (EPS) Terhadap Price To Book Value (PBV) Pada Perusahaan Transportasi di Bursa Efek Indonesia Periode 2008-2012. Dari hasil pengujian secara parsial diperoleh hasil bahwa dua 
variabel yaitu Dept Equity Ratio (DER) dan Earning per Share (EPS) mempunyai pengaruh yang signifikan terhadap Price To Book Value (PBV). Sedangkan Return on Assets (ROA) tidak berpengaruh signifikan terhadap Price To Book Value (PBV).

\section{Hipotesis}

H1: CAR berpengaruh signifikan terhadap PBV saham industri perbankan

$\mathrm{H} 2$ : NPL berpengaruh signifikan terhadap PBV saham industri perbankan

H3: LDR berpengaruh signifikan terhadap PBV saham industri perbankan

H4: ROE berpengaruh signifikan terhadap PBV saham industri perbankan.

H5: NIM berpengaruh signifikan terhadap PBV saham industri perbankan

H6: BOPO berpengaruh signifikan terhadap PBV saham industri perbankan

H7: CAR, NPL, LDR, ROE, NIM, dan BOPO berpengaruh signifikan terhadap PBV saham industri perbankan secara simultan

\begin{tabular}{l}
\hline METODE PENELITIAN \\
$\begin{array}{c}\text { Populasi dan Sampel } \\
\text { Populasi adalah }\end{array}$ \\
generalisasi yang terdiri atas obyek/ \\
subyek yang mempunyai kualitas dan \\
karakteristik tertentu yang ditetapkan oleh \\
peneliti untuk dipelajari dan kemudian \\
ditarik kesimpulannya. Jadi populasi buka \\
hanya orang, tetapi juga obyek dan benda- \\
benda alam yang lain. Populasi juga bukan \\
sekedar jumlah yang ada pada \\
obyek/subyek yang dipelajari, tetapi \\
meliputi seluruh karakteristik/sifat yang \\
dimiliki oleh subyek atau obyek tersebut. \\
Populasi dalam penelitian ini adalah semua \\
perusahaan perbankan yang terdaftar di
\end{tabular}

Bursa Efek Indonesia (BEI). Jumlah populasi adalah 41 perusahaan perbankan yang terdaftar di Bursa Efek Indonesia.

Sampel adalah bagian dari jumlah dan karakteristik yang dimiliki oleh populasi tersebut. Bila populasi besar, dan peneliti tidak mungkin mempelajari semua yang ada pada populasi, misalnya karena keterbatasan dana, tenaga dan waktu, maka peneliti dapat menggunakan sampel yang diambil dari populasi itu. Apa yang dipelajari dari sampel itu, kesimpulannya akan dapat diberlakukan untuk populasi. Untuk itu sampel yang diambil dari populasi harus betul-betul representatif (mewakili).

\section{Teknik Analisis Data}

1. Uji Asumsi Klasik

Pengujian asumsi klasik menurut Nurdiansyah (2014) merupakan pengujian asumsi-asumsi statistik yang harus dipenuhi pada analisis regresi linier berganda yang berbasis ordinary least square (OLS). Pada penelitian ini, asumsi klasik yang dilakukan antara lain:

\section{Uji Normalitas data}

Asumsi normalitas adalah asumsi residual yang berdistribusi normal. Asumsi ini harus terpenuhi untuk model regresi linier yang baik. Uji normalitas dilakukan pada nilai residual model regresi. Penyebab terjadinya kasus normalitas adalah

\section{Uji Autokorelasi}

Menurut Kusuma dan Ismanto (2012), secara harfiah autokorelasi berarti adanya korelasi antara anggota observasi satu dengan observasi lain yang berlainan waktu.dalam kaitannya dengan asumsi model OLS, autokorelasi merupakan korelasi antara satu variable gangguan dengan variable gangguan yang lain. Sedangkan salah satu asumsi penting metode OLS berkaitan dengan variable gangguan adalah tidak adanya 
hubungan antara variable gangguan satu dengan variable gangguan yang lain. Autokorelasi lebih mudah terjadi pada data yang bersifat runtut waktu (time series), karena sifat datanya yang biasanya dipengaruhi oleh data sebelumnya. Autokorelasi juga mungkin terjadi pada data antar obyek (cross section). Autokorelasi dapat berbentuk positif dan negatif. Autokorelasi pada regresi linier dapat meyebabkan terjadinya kebiasan pada saat kesimpulan diambil.

\section{Uji Multikolinearitas}

Multikolinearitas menurut Kusuma dan Ismanto (2012) merupakan salah satu masalah dalam analisis regresi denga OLS yang berarti terdapat korelasi atau hubungan yang sangat tinggi diantara variable independen. Multikolinearitas hanya terjadi pada regresi majemuk, karena melibatkan beberapa variable independen sehingga tidak terjadi pada regresi sederhana.

\section{Uji Heteroskedastisitas}

Heteroskedastisitas

menurut

Kusuma dan Ismanto (2012) adalah kondisi dimana nilai varians error untuk setiap data pengamatan tidak konstan atau $\operatorname{var}\left(\mathrm{e}_{\mathrm{i}}\right)=\sigma_{2 i}$. Salah satu asumsi dalam model regresi dengan model regresi dengan OLS adalah nilai error atau residual memiliki varians yang konstan $\operatorname{var}\left(\mathrm{e}_{\mathrm{i}}\right)=\sigma_{2}$ atau disebut juga homoskedastisitas. Pada kenyataannya nilai residual sulit memiliki varians konstan, yang membuat nilai taksiran varians dan standar error koefisien regresi menjadi tidak efisien (underestimate) sehingga pengujian hipotesis dengan uji $t$ menjadi tidak valid (overestimate). Heteroskedastisitas sering dijumpai pada data yang sifatnya cross section daripada time series.

\section{Uji Hipotesis}

1. Uji Parsial (Uji T)

2. Uji Simultan (Uji F)

Untuk menguji pengaruh variabel independen terhadap variabel dependen, dilakukan dengan Uji $t$ statistik dimaksudkan untuk menguji signifikansi dari setiap variabel independen dalam menentukan arah gerakan variabel dependen pada tahun pengamatan. Taraf signifikansi $(\alpha)$ ditetapkan sebesar 5\%.

\section{Uji Koefisien Determinasi}

Koefisien determinasi dapat digunakan sebagai petunjuk untuk mengetahui sejauh mana variabel independen dapat menjelaskan variasi variabel dependen. Besarnya koefisien determinasi adalah kuadrat dari koefisien korelasi (Algifari,2010).

\section{HASIL PENELITIAN DAN PEMBAHASAN}

\section{Hasil Statistk Deskriptif}

Hasil uji statistic deskriptif

\begin{tabular}{|c|c|c|c|c|c|c|}
\hline & CAR & NPL & LDR & NIM & ROE & BOPO \\
\hline $\mathbf{N}$ & 38 & 38 & 38 & 38 & 38 & 38 \\
\hline Mean & 16,43 & 1,87 & 86,36 & 4,65 & 6,03 & 83,27 \\
\hline Median & 15,66 & 1,69 & 85,40 & 4,68 & 11,15 & 84,94 \\
\hline Minimum & 10,44 & 0,20 & 57,41 & 0,24 & $-142,48$ & 33,28 \\
\hline Maximum & 27,91 & 6,88 & 140,72 & 9,60 & 28,20 & 137,80 \\
\hline
\end{tabular}

\section{Teknik Analisis Data}

Uji Asumsi Klasik

\section{Uji Normalitas}

Hasil Uji Normalitas

\begin{tabular}{|l|l|l|l|l|}
\hline Variabel & Prob. Jarque-Bera & & Alpha & Keterangan \\
\hline Residual & 0.135 & $>$ & 0.05 & Normal \\
\hline
\end{tabular}

Berdasarkan hasil uji normalitas menggunakan uji Jarque-Bera, dapat disimpulkan bahwa residual persamaan regresi pada data yang diolah mempunyai distribusi normal. Hal ini ditunjukkan pada nilai prob. J-B yang sebesar 0,135 , yang mana lebih besar dari $\alpha 5 \%(0,135>5 \%)$. 
Uji Autokorelasi

Hasil uji Autokorelasi

\begin{tabular}{|l|l|l|l|l|l|l|}
\hline Variabel & Dl & & D & & dU & Keterangan \\
\hline $\begin{array}{l}\text { CAR, NPL, LDR, } \\
\text { NIM, ROE, BOPO }\end{array}$ & 1,15 & $<$ & 1,31 & $<$ & 1,86 & Tidak ada kesimpulan \\
\hline
\end{tabular}

Berdasarkan hasil uji autokorelasi menggunakan Durbin-Watson diperoleh hasil bahwa tidak terdapat kesimpulan apakah pada data yang diolah terdapat autokorelasi atau tidak. Hal ini ditunjukan dengan nilai dL yaitu 1,15 lebih kecil dari hasil uji Durbin-Watson sebesar 1,31 yang lebih kecil dari nilai dU 1,86. Dari hasil tersebut maka pada uji autokorelasi tidak menghasilkan kesimpulan.

\section{Uji Multikolineritas}

\begin{tabular}{|c|c|c|c|c|c|c|c|}
\hline \multicolumn{8}{|c|}{ Hasil Uji Multikolinearitas } \\
\hline $\begin{array}{l}\text { Variabel } \\
\end{array}$ & CAR & NPL & LDR & NIM & ROE & BOPO & $\begin{array}{l}\text { Keterangan } \\
\end{array}$ \\
\hline CAR & 1,00 & $-0,19$ & 0,46 & 0,04 & $\overline{0,14}$ & $-0,43$ & Hasil \\
\hline NPL & $-0,19$ & 1,00 & $-0,10$ & $-0,29$ & $-0,45$ & $\overline{0,52}$ & pengujian \\
\hline LDR & 0,46 & $-0,10$ & 1,00 & $-0,10$ & $-0,03$ & $-0,32$ & $<0,90$ \\
\hline NIM & 0,04 & $-0,29$ & $-0,10$ & 1,00 & 0,49 & $-0,36$ & \\
\hline ROE & 0,14 & $-0,45$ & $-0,03$ & 0,49 & 1,00 & $-0,70$ & \\
\hline ВОРО & $-0,43$ & 0,52 & $-0,32$ & $-0,36$ & $-0,70$ & 1,00 & \\
\hline
\end{tabular}

Berdasarkan hasil pengujian korelasi antar variabel independen, terlihat bahwa nilai korelasi atar variabel cukup rendah. Hal ini menunjukan tidak adanya gejala multikolinearitas pada data penelitian ini.

\section{Uji Heteroskedastisitas}

Hasil Uji Heteroskedastisitas

\begin{tabular}{|c|c|c|c|c|}
\hline variabel & Prob. Chi square & & Alpha & Keterangan \\
\hline Residual & 0,09 & $>$ & 0,05 & Tidak terjadi heteroskedastisitas \\
\hline
\end{tabular}

Dari hasil pengujian terhadap gejala heteroskedastisitas dengan uji BreuschPagan-Godfrey (BPG) menunjukkan nilai prob. Chi-square pada Obs*R-squared lebih besar dari 0,05. Jadi, pada data penelitian ini tidak terjadi masalah heteroskedastisitas.

\section{Hasil Penelitian}

1. Hasil Uji Regresi Data Panel Tabel 4.6

Hasil Perhitungan Regresi

\begin{tabular}{|c|c|}
\hline Variabel & Coefficient \\
\hline C & $-5,0871$ \\
\hline CAR & 0,1342 \\
\hline NPL & $-0,7621$ \\
\hline LDR & $-0,0678$ \\
\hline NIM & 0,8076 \\
\hline ROE & 0,0148 \\
\hline BOPO & 0,1029 \\
\hline
\end{tabular}

Sumber : Data Sekunder diolah, 2015

$P B V=-5,0871+0,1342 C A R-0,7621 N P L-0,0672 L D R+0,8070 \mathrm{NM}+0,0148 R 0 \mathrm{E}+0,1029 \mathrm{BOPO}+\mathrm{e}$

a. Konstanta sebesar -5,0871, artinya jika CAR (X1), NPL (X2), LDR (X3), NIM (X4), ROE (X5) dan BOPO (X6) nilainya adalah 0 , maka besarnya PBV saham industri perbankan (Y) adalah -5,0871.

b. Koefisien regresi variabel CAR (X1) sebesar 0,1342, artinya jika variabel independen lainnya nilainya tetap dan CAR naik satu satuan maka nilai PBV saham industri (Y) perbankan naik 0,1342. Koefisien bernilai positif artinya semakin tinggi CAR maka semakin tinggi pula nilai PBV saham industri perbankan.

c. Koefisien regresi variabel NPL (X2) sebesar -0,7621, artinya jika variabel independen lainnya nilainya tetap dan NPL naik satu satuan maka nilai PBV saham industri (Y) perbankan turun 0,7621. Koefisien bernilai negative artinya semakin tinggi NPL maka semakin rendah nilai PBV saham industri perbankan.

d. Koefisien regresi variabel LDR (X3) sebesar -0,0678, artinya jika variabel independen lainnya nilainya tetap dan LDR naik satu satuan maka nilai PBV saham industri (Y) perbankan turun 
0,0678. Koefisien bernilai negative artinya semakin tinggi LDR maka semakin rendah nilai PBV saham industri perbankan.

e. Koefisien regresi variabel NIM (X4) sebesar 0,8076 , artinya jika variabel independen lainnya nilainya tetap dan NIM naik satu satuan maka nilai PBV saham industri (Y) perbankan naik 0,8076. Koefisien bernilai positif artinya semakin tinggi NIM maka semakin tinggi pula nilai PBV saham industri perbankan.

f. Koefisien regresi variabel ROE (X5) sebesar 0,0148, artinya jika variabel independen lainnya nilainya tetap dan ROE naik satu satuan maka nilai PBV saham industri (Y) perbankan naik 0,0148. Koefisien bernilai positif artinya semakin tinggi ROE maka semakin tinggi pula nilai PBV saham industri perbankan.

g. Koefisien regresi variabel BOPO (X6) sebesar 0,1029, artinya jika variabel independen lainnya nilainya tetap dan BOPO naik satu satuan maka nilai $\mathrm{PBV}$ saham industri $(\mathrm{Y})$ perbankan naik 0,1029. Koefisien bernilai positif artinya semakin tinggi BOPO maka semakin tinggi pula nilai PBV saham industri perbankan.

2. Hasil Uji Parsial (Uji T)

Hasil Uji Parsial

\begin{tabular}{|c|c|}
\hline Variabel & Prob. \\
\hline CAR & 0,019 \\
\hline NPL & 0,018 \\
\hline LDR & 0,000 \\
\hline NIM & 0,003 \\
\hline ROE & 0,080 \\
\hline BOPO & 0,002 \\
\hline
\end{tabular}

Berdasarkan tabel diatas dapat diketahui apakah variabel independen berpengaruh terhadap variabel dependen dengan taraf signifikansi alpha ditetapkan sebesar 5\%.

Pengujian yang pertama yaitu menguji adanya pengaruh variabel independen CAR terhadap Variabel dependen PBV. Dari tabel diatas, diketahui nilai probabilitas CAR sebesar 0,019. Nilai probabilitas CAR sebesar 0,019 lebih kecil dari alpha yang digunakan dalam penelitian ini yaitu sebesar 0,05 Hal ini menunjukan bahwa CAR64 berpengaruh signifikan terhadap PBV saham industri perbankan, maka Ha1 diterima dan $\mathrm{H} 01$ ditolak.

Selanjutnya adalah pengujian hipotesis kedua yaitu apakah NPL berpengaruh terhadap PBV saham industri perbankan. Dari tabel diatas, diketahui nilai probabilitas NPL sebesar 0.018. Nilai probabilitas NPL sebesar 0.018 lebih kecil dari alpha yang digunakan dalam penelitian ini yaitu sebesar 0,05. Hal ini menunjukan bahwa NPL berpengaruh signifikan terhadap PBV saham industri perbankan, maka Ha2 ditolak dan $\mathrm{H} 02$ diterima.

Kemudian pengujian hipotesis ketiga yaitu apakah LDR berpengaruh terhadap

PBV saham industri perbankan. Dari tabel diatas, diketahui nilai probabilitas LDR\sebesar 0.000. Nilai probabilitas LDR sebesar 0.000 lebih kecil dari alpha yang digunakan dalam penelitian ini yaitu sebesar 0,05 . Hal ini menunjukan bahwa LDR berpengaruh signifikan terhadap PBV saham industri perbankan, maka $\mathrm{Ha} 3$ diterima dan $\mathrm{H} 03$ ditolak.

Pengujian hipotesis keempat dilakukan untuk mengetahui apakah NIM berpengaruh terhadap PBV saham industri perbankan. Dari tabel diatas, diketahui nilai probabilitas NIM sebesar 0.003. Nilai probabilitas NIM sebesar 0.003 lebih besar dari alpha yang digunakan dalam penelitian ini yaitu 
sebesar 0,05. Hal ini menunjukan bahwa NIM berpengaruh signifikan terhadap PBV saham industri perbankan, maka $\mathrm{Ha} 4$ diterima dan $\mathrm{H} 04$ ditolak.

Selanjutnya adalah pengujian hipotesis ke lima yaitu apakah ROE berpengaruh terhadap PBV saham industri perbankan. Dari tabel diatas, diketahui nilai probabilitas ROE sebesar 0.080. Nilai probabilitas ROE sebesar 0.080 lebih besar dari alpha yang digunakan dalam penelitian ini yaitu sebesar 0,05 . Hal ini menunjukan bahwa ROE tidak berpengaruh signifikan terhadap PBV saham industri perbankan, maka Ha5 ditolak dan $\mathrm{H} 05$ diterima.

Pengujian yang terakhir adalah pengujian hipotesis keenam yaitu apakah BOPO berpengaruh terhadap PBV saham industri perbankan. Dari tabel diatas, diketahui nilai probabilitas BOPO sebesar 0.002. Nilai probabilitas BOPO sebesar 0.002 lebih kecil dari alpha yang digunakan dalam penelitian ini yaitu sebesar 0,05. Hal ini menunjukan bahwa LDR berpengaruh terhadap PBV saham industri perbankan, maka Ha6 diterima dan H06 ditolak

\section{Hasil Uji Simultan (Uji F)}

\begin{tabular}{|c|c|}
\hline Variabel & Prob. \\
\hline F Statistik & 0,000 \\
\hline Data sekunder diolah, 2015
\end{tabular}

Berdasarkan tabel diatas, diketahui nilai probabilitas F-statistik 0,000 dimana lebih kecil dari alpha yang ditetapkan sebesar 0,05. Jadi dapat disimpulkan bahwa dengan pengujian secara simultan, variabel independen Capital Adequacy Ratio (CAR), Non Performing Loan (NPL), Net Interest Margin (NIM), Loan to Deposit Ratio (LDR), Return on Equity (ROE) dan Biaya Operasional per Pendapatan Operasi (BOPO) secara bersama-sama berpengaruh signifikan terhadap variabel dependen Price to Book Value (PBV) saham industri perbankan.

\section{Pembahasan}

1. Pengaruh Capital Adequacy Ratio (CAR) terhadap Price to Book Value (PBV) saham industri perbankan (Ha1). Pengujian yang pertama yaitu menguji adanya pengaruh variabel independen CAR terhadap Variabel dependen PBV. Dari hasil pengujian ini, diketahui bahwa Variabel CAR berpengaruh signifikan terhadap PBV saham industri perbankan. Dengan demikian Ha1 yang menyatakan bahwa CAR berpengaruh signifikan terhadap PBV saham industri perbankan diterima. Hal ini dilihat dari nilai probabilitas CAR sebesar 0.019 lebih kecil dari alpha yang digunakan dalam penelitian ini yaitu sebesar $0,05(0,019$ $<0,05)$. Dengan demikian, penelitian ini mendukung penelitian yang dilakukan oleh Hasan (2011) yang menyatakan bahwa variabel Capital Adequacy Ratio (CAR) berpengaruh terhadap Price to book Value (PBV) saham industri perbankan. Artinya, besaran penyediaan modal minimum yang harus dimiliki oleh bank berpengaruh secara signifikan terhadap hubungan antara harga pasar saham dan nilai buku per lembar saham atau dalam penelitian ini menunjukkan bahwa Capital Adequacy Ratio (CAR) berpengaruh secara signifikan terhadap Price to Book Value (PBV) saham industri perbankan.

2. Pengaruh Non Performing Loan (NPL) terhadap Price to Book Value (PBV) sahamindustri perbankan (Ha2). Pengujian yang kedua yaitu menguji adanya pengaruh variabel independen NPL terhadap Variabel dependen PBV. Dari hasil pengujian ini, diketahui bahwa Variabel NPL berpengaruh signifikan terhadap PBV saham industri perbankan. Dengan demikian 
Ha2 yang menyatakan bahwa NPL berpengaruh signifikan terhadap PBV saham industri perbankan diterima. Hal ini dilihat dari nilai probabilitas NPLsebesar 0.018. Nilai probabilitas NPL sebesar 0.018 lebih kecil dari alpha yang digunakan dalam penelitian ini yaitu sebesar $0,05(0,018>0,05)$. Dengan demikian, penelitian ini tidak mendukung penelitian yang dilakukan oleh Hasan (2011) yang menyatakan bahwa variabel Non Performing Loan (NPL) tidak berpengaruh terhadap Price to book Value (PBV) saham industri perbankan. Artinya, besaran rasio kredit bermasalah berpengaruh secara signifikan terhadap hubungan antara harga pasar saham dan nilai buku per lembar saham atau dalam penelitian ini menunjukkan bahwa Non Performing Loan (NPL) berpengaruh secara signifikan terhadap Price to Book Value (PBV) saham industri perbankan.

3. Pengaruh Loan to Dept Ratio (LDR) terhadap Price to Book Value (PBV) saham industri perbankan (Ha3). Pengujian yang ketiga yaitu menguji adanya pengaruh variabel independen LDR terhadap Variabel dependen PBV. Dari hasil pengujian ini, diketahui bahwa Variabel LDR berpengaruh signifikan terhadap PBV saham industri perbankan. Dengan demikian Ha3 yang menyatakan bahwa LDR berpengaruh signifikan terhadap PBV saham industri perbankan diterima. Hal ini dilihat dari nilai probabilitas LDR sebesar 0.000 lebih besar dari alpha yang digunakan dalam penelitian ini yaitu sebesar $0,05(0,000$ $<0,05)$. Dengan demikian, penelitian ini tidak mendukung penelitian yang dilakukan oleh Hasan (2011) yang menyatakan bahwa variabel Loan to Deposit Ratio (LDR) tidak berpengaruh terhadap Price to book Value (PBV) saham industri perbankan. Artinya, rasio antara seluruh jumlah kredit yang diberikan bank dengan dana yang diterima bank berpengaruh secara signifikanterhadap hubungan antara harga pasar saham dan nilai buku per lembar saham atau dalam penelitian ini menunjukkan bahwa Loan to Deposit Ratio (LDR) berpengaruh signifikan terhadap Price to Book Value (PBV) saham industri perbankan.

4. Pengaruh Net Interest Margin (NIM) terhadap Price to Book Value (PBV) saham industri perbankan (Ha4). Pengujian hipotesis keempat dilakukan untuk mengetahui apakah NIM berpengaruh terhadap PBV saham industri perbankan. Dari hasil pengujian ini, diketahui bahwa Variabel NIM berpengaruh signifikan terhadap PBV saham industri perbankan. Dengan demikian Ha4 yang menyatakan bahwa NIM berpengaruh signifikan terhadap PBV saham industri perbankan diterima. Hal ini dilihat dari nilai probabilitas NIM sebesar 0,003 lebih kecil dari alpha yang digunakan dalam penelitian ini yaitu sebesar $0,05(0,003<0,05)$. Dengan demikian, penelitian ini mendukung penelitian yang dilakukan oleh Hasan (2011) yang menyatakan bahwa variabel Net Interest Margin (NIM) berpengaruh terhadap Price to book Value (PBV) saham industri perbankan. Artinya, rasio yang digunakan untuk mengetahui seberapa besar kemampuan bank untuk mengelola seluruh aktiva produktifnya agar bisa menghasilkan penghasilan netto yang lebih tinggi berpengaruh secara signifikan terhadap hubungan antara harga pasar saham dan nilai buku per lembar saham atau dalam penelitian ini menunjukkan bahwa Net Interest Margin (NIM) berpengaruh signifikan terhadap Price to Book Value (PBV) saham industri perbankan. 
5. Pengaruh Return on Equity (ROE) terhadap Price to Book Value (PBV) saham industri perbankan (Ha5). Selanjutnya adalah pengujian hipotesis ke lima yaitu apakah ROE berpengaruh terhadap PBV saham industri perbankan. Dari hasil pengujian ini,72 diketahui bahwa Variabel ROE tidak berpengaruh signifikan terhadap PBV saham industri perbankan. Dengan demikian Ha5 yang menyatakan bahwa ROE berpengaruh signifikan terhadap PBV saham industri perbankan ditolak. Hal ini dilihat dari Nilai probabilitas ROE sebesar 0.080 lebih besar dari alpha yang digunakan dalam penelitian ini yaitu sebesar $0,05(0,080>0,05)$. Dengan demikian,penelitian ini tidak mendukung penelitian yang dilakukan oleh Hasan (2011) yang menyatakan bahwa variabel Return on Equity (ROE) berpengaruh terhadap Price to book Value (PBV) saham industri perbankan. Artinya, perbandingan antara laba bersih bank dengan modal sendiri tidak berpengaruh signifikan terhadap hubungan antara harga pasar saham dan nilai buku per lembar saham atau dalam penelitian ini menunjukkan bahwa Return on Equity (ROE) tidak berpengaruh secara signifikan terhadap Price to Book Value (PBV) saham industri perbankan.

6. Pengaruh Biaya Operasional per Pendapatan Operasional (BOPO) terhadap Price to Book Value (PBV) saham industri perbankan (Ha6). Selanjutnya adalah pengujian hipotesis keenam yaitu apakah BOPO berpengaruh terhadap PBV saham industri perbankan. Dari hasil pengujian ini, diketahui bahwa Variabel BOPO berpengaruh signifikan terhadap PBV saham industri perbankan. Dengan demikian Ha6 yang menyatakan bahwa BOPO berpengaruh signifikan terhadap PBV saham industri perbankan diterima. Hal ini dilihat dari Nilai probabilitas BOPO sebesar 0.002 lebih kecil dari alpha yang digunakan dalam penelitian ini yaitu sebesar $0,05(0,002<0,05)$. Dengan demikian,73 penelitian ini mendukung penelitian yang dilakukan oleh Hasan (2011) yang menyatakan bahwa variabel Biaya Operasional per Pendapatan Operasional (BOPO) berpengaruh terhadap Price to book Value (PBV) saham industri perbankan. Artinya, perbandingan antara biaya operasional dan pendapatan operasional berpengaruh signifikan terhadap hubungan antara harga pasar saham dan nilai buku per lembar saham atau dalam penelitian ini menunjukkan bahwa Biaya Operasional per Pendapatan Operasional (BOPO) berpengaruh secara signifikan terhadap Price to Book Value (PBV) saham industri perbankan.

7. Pengaruh Capital Adequacy Ratio (CAR), Non Performing Loan (NPL), Loan to Deposit Ratio (LDR), Return on Equity (ROE), Net Interest Margin (NIM) dan Biaya Operasional per Pendapatan Operasi (BOPO) secara simultan terhadap PBV saham industri perbankan. Yang terakhir adalah pengujian variabel independen Capital Adequacy Ratio (CAR), Non Performing Loan (NPL), Net Interest Margin (NIM), Loan to Deposit Ratio (LDR), Return on Equity (ROE) dan Biaya Operasional per Pendapatan Operasi (BOPO) terhadap variabel dependen Price to Book Value (PBV) saham industri perbankan secara simultan atau secara bersama-sama. Dari hasil pengujian ini menunjukkan bahwa secara bersama-sama variabel independen CAR, NPL, LDR, NIM, ROE dan BOPO berpengaruh signifikan terhadap variabel dependen PBV saham industri perbankan. Dengan demikian Ha7 yang menyatakan bahwa CAR, NPL, LDR, 
ROE, NIM, dan BOPO berpengaruh signifikan terhadap PBV saham bank secara simultan. Hal ini dapat dilihat dari nilai probabilitas F-statistik 0,000 yang lebih kecil dari alpha yang telah ditetapkan yaitu $5 \%(0,000<0,05)$. Dengan demikian, penelitian ini mendukung penelitian yang dilakukan oleh Hasan (2011) yang menyatakan bahwa Capital Adequacy Ratio (CAR), Non Performing Loan (NPL), Loan to Deposit Ratio (LDR), Return on Equity (ROE), Net Interest Margin (NIM) dan Biaya Operasional per Pendapatan Operasi (BOPO) secara simultan berpengaruh signifikan terhadap Price to book Value (PBV) saham industri perbankan. Yang terakhir adalah pengujian Koefisien determinasi yang digunakan sebagai petunjuk untuk mengetahui sejauh mana variabel independen dapat menjelaskan variasi variabel dependen. Diketahui nilai R-Squared (R2) sebesar 0,976. Hal tersebut menunjukkan bahwa variabel independen Capital Adequacy Ratio (CAR), Non Performing Loan (NPL), Net Interest Margin (NIM), Loan to Deposit Ratio (LDR), Return on Equity (ROE) dan Biaya Operasional per Pendapatan Operasi (BOPO) berpengaruh terhadap variabel dependen Price to Book Value (PBV) saham industri perbankan sebesar 0,976 atau sebesar $97,6 \%$ dan sisanya $2,4 \%$ dipengaruhi oleh variabel lain yang tidak ada dalam model.

\section{KESIMPULAN DAN SARAN}

\section{Kesimpulan}

Secara umum, penelitian ini bertujuan untuk menganalisis faktor-faktor yang mempengaruhi price to book value saham pada bank devisa yang listing di bursa efek indonesia periode 2013-2014 dengan menggunakan indikator rasio keuangan CAR (Capital Adequacy Ratio), NPL (Non Performing Loan), LDR (Loan to Deposit ratio), NIM (Net Interst
Margin), ROE (Return on Equity) dan BOPO (Biaya operasional per pendapatan Operasional) sebagai variabel independen dan PBV (Price to Book Value) sebagai variabel dependen. Penelitian ini menyimpulkan bahwa :

1. Secara parsial menunjukan bahwa :

a. Variabel CAR (Capital Adequacy Ratio) berpengaruh signifikan terhadap PBV saham industri perbankan. Hal ini dilihat dari nilai probabilitas CAR sebesar 0.019 lebih kecil dari alpha yang digunakan dalam penelitian ini yaitu sebesar $0,05(0,019<0,05)$.

b. Variabel NPL (Non Performing Loan) berpengaruh signifikan terhadap PBV saham industri perbankan. Hal ini dilihat dari nilai probabilitas NPL sebesar 0.018. Nilai probabilitas NPL sebesar 0.018 lebih kecil76 dari alpha yang digunakan dalam penelitian ini yaitu sebesar $0,05(0,018<0,05)$.

c. Variabel LDR (Loan to Deposit ratio) LDR berpengaruh signifikan terhadap PBV saham industri perbankan. Hal ini dilihat dari nilai probabilitas LDR sebesar 0.000 lebih kecil dari alpha yang digunakan dalam penelitian ini yaitu sebesar $0,05(0,000<0,05)$.

d. Variabel NIM (Net Interst Margin) berpengaruh signifikan terhadap PBV saham industri perbankan. Hal ini dilihat dari nilai probabilitas NIM sebesar 0.003 lebih kecil dari alpha yang digunakan dalam penelitian ini yaitu sebesar $0,05(0,003<0,05)$.

e. Variabel ROE (Return on Equity) tidak berpengaruh signifikan terhadap PBV saham industri perbankan. Hal ini dilihat dari Nilai probabilitas ROE sebesar 0.080 lebih besar dari alpha yang digunakan dalam penelitian ini yaitu sebesar $0,05(0,080>0,05)$.

f. Variabel BOPO (Biaya operasional per pendapatan Operasional) berpengaruh signifikan terhadap PBV saham industri perbankan.Hal ini dilihat dari Nilai probabilitas BOPO sebesar 0.002 lebih kecil dari alpha yang digunakan dalam 
penelitian ini yaitu sebesar $0,05(0,002$ $<0,05)$.

\section{Saran}

Berdasarkan pada permasalahan yang diangkat oleh peneliti yaitu mengenai analisis faktor-faktor yang mempengaruhi price to book value saham pada bank devisa yang listing di bursa efek indonesia periode 2013-2014, maka dari itu saran bagi penelitian berikutnya adalah sebagai berikut:

1. Bagi Investor

Bagi investor yang hendak melakukan investasi dalam bentuk saham hendaknya melakukan analisis klebih lanjut tentang faktor yang mempengaruhi Price to Book Value saham sehingga investor dapat menentukan apakah saham tersebut dalam keadaan undervalue atau overvalue.

\section{Bagi Perbankan}

Bagi industri perbankan disarankan untuk lebih meningkatkan kinerjanaya dalam segala aspek agar nilai Price to Book Value saham dapat meningkat sehingga investor akan tertarik untuk berinvestasi pada saham industry perbankan.

3. Bagi peneliti selanjutnya

Pada penelitian hendaklah menggunakan rasio keuangan lain untuk mencari faktor-faktor yang berpengaruh terhadap Price to Book Value saham, seperti : Net Profit Margin (NPM), Return on Assets (ROA), Dept Equity Ratio (DER), Earning per Share (EPS), dan sebagainya.

\section{DAFTAR PUSTAKA}

Algifari. 2010. Statistika Deskriptif Plus Untuk Ekonomi dan Bisnis. Yogyakarta: UPP STIM YKPN.

Al-Hafizh, Mushlihin. Pengertian Kinerja Keuangan.

http://www. referensimakalah. com /2013/02 /pengertian-kinerja-keuangan.html. Diakses 1 november 2015.

Apa itu Net Interest Margin atau NIM dan Bagaimana Mengelola NIM. Didapatkan http://ahliperbankan. com/apa-itu-net-interest-marginatau-nim-danbagaimana mengelola-nim . diakses 27 oktober 2015

Aziz, Yohana Paulia. 2014. Analisis Pengaruh Dept Equity Ratio (DER), Return on Assets (ROA), Earning per Share (EPS) Terhadap Price To Book Value (PBV) Pada Perusahaan Transportasi di Bursa Efek Indonesia Periode 2008-2012. Skripsi. Yogyakarta: FE UAD

BI. 2009. Outlook Ekonomi Indonesia 2009 - 2014 : Krisis Finansial Global dan Dampaknya terhadap Perekonomian Indonesia. Didapat: http://www.bi.go.id/id/publikasi/kebi jakan-moneter/outlook-ekonomi/ Documents/4fd34648c8724da7b93e 4f8021850012Bab3KrisisEkonomiG lobalda

nDampaknyaterhadapPerekon.pdf. diakses 29 september 2015

BI. 2013. Surat Edaran Eksternal Bank Indonesia Nomor: 15/27/DPNP Tanggal 19 Juli 2013 Perihal Persyaratan Bank Umum Untuk Melakukan Kegiatan Usaha Dalam Valuta Asing. Didapat: www.bi.go.id/id/peraturan/ perbankan/documents/1b011c1e1315 47e3846c4ae5b0b9cd8Bse15_27_D PNP.P df. diakses 24 November 2015 Bi.co.id. diakses November 2015

Darmaji, Tjiptono dan Fakhrudin, Hendy M., 2007. Pasar Modal Di Indonesia pendekatan Tanya jawab. Jakarta : salemba empat. 
Definifi NPL. Didapat: <http://ekonomi.kabo.biz/2011/11/no n-performing-financingnpf.html> . diakses 21 Oktober 2015

Dendawijaya, Lukman, 2009. Manajemen Perbankan. Bogor : Ghalia Indonesia

Hasan, Mudrika Alamsyah, 2011. Analisis Faktor yang mempengaruhi Price to Book Value saham (pada bank yang terdaftar di Bursa Efek Indonesia periode 2005- 2008). Pekbis jurnal. Vol.3. no.3. November;536-548.

http://ejournal.unri.ac.id/index.php/JPEB/a rticle/view/419. diakses 15 september 2015IDX. Saham. http://www.idx.co.id/id-

$\mathrm{id} /$ beranda/produkdanlayanan/saham .aspx . Diakses 21 oktober 2015 Idx.co.id. diakses 29 November 2015.

Kasmir,2012. Bank dan Lembaga Keuangan Lainnya.jakarta : rajagrafindo persada.

Kusuma, Desta R, dan Ismanto, Deny.2012. modul Praktikum Eviews. Yogyakarta: Universitas Ahmad Dahlan

Marlina, 2013. Pengaruh Earning Per Share, Return On Equity, Debt To Equity Ratio dan Size Terhadap Price To Book Value. http:// www.google.co.idurlsa $=\mathrm{t} \& \mathrm{rct}=\mathrm{j} \& \mathrm{q}=$ $\&$ esrc $=$ s\&source $=$ web \&cd $=16 \& c a d$ $=$ rja\&u act $=8 \&$ ved $=0 \mathrm{CDwQFjAFOApqFQo}$ TCNOI75Dy2MgCFQyejgod7jIFbw \&url= http\%3A\%2F\%2Fjurnal.stiekesatuan .ac.id\%2Findex.php\%2Fjiak\%2Farti cle $\% 2$ F. diakses 23 oktober 2015

Nurdiansyah, Denny, 2014. Uji Asumsi Klasik Regresi Linier. Didapatkan < http://www. statsdata. my.id/2014/06/uji-asumsi-klasikregresi-linier.html>. Diakses 28 Oktober 2015.

Pengertian Non Performing Loan dan contoh ilustrasinya. https://pandusamamaya.wordpress.c om/2012/05/08/pengertian-nonperformingloan-npl-dan-contohilustrasinya/ . Diakses 21 Oktober 2015 SahamOK.co.id. Diakses 20 September 2015.

Widarjoni, Agus.2009. ekonometrika Pengantar dan Aplikasinya. Yogyakarta: Ekonisia.

Zulaiha, Leli, 2013. Analisis pengaruh tingkat kesehatan bank terhadap perubahan harga saham pada perusahaan perbankan yang gopublic di Bursa Efek Indonesia periode 2009-2011. Skripsi. Yogyakarta: FE UAD 